\title{
A CARTA DEL PAISAJE DE LAS AMÉRICAS: UMA COMPREENSÃO RESPONSIVA
}

\author{
THE CARTA DEL PAISAJE DE LAS AMÉRICAS: A RESPONSIVE UNDERSTANDING \\ LA CARTA DEL PAISAJE DE LAS AMÉRICAS: UNA COMPRENSIÓN RESPONSIVA
}

\section{RESUMO}

Introdução: $O$ presente artigo é resultado de uma compreensão dialógica e crítica da recém-publicada Carta del Paisaje de las Américas, e nele procura-se descobrir as características singulares desta Carta em relação à outras Cartas da Paisagem já redigidas nas Américas. $\mathrm{O}$ texto, de forma geral indaga em que medida o dito documento se trata de um instrumento e, se o for, em que medida é um instrumento que garante o direito à felicidade como bem patrimonial coletivo das Américas. Objetivo: $\mathrm{O}$ objetivo do presente artigo é interpelar a Carta enquanto instrumento que garantirá o direito à felicidade como bem patrimonial coletivo das Américas. Métodos (opcional): Para atingir ao objetivo exposto recorreu-se a leitura dialética de todas as Cartas da Paisagem já produzidas em âmbito nacional e regional nas Américas a fim de compreender o gênero discursivo - categoria ancorada à concepção dialógica da linguagem desenvolvida por Mikhail Bakhtin e seu círculo - ao qual pertence o documento em epígrafe neste artigo. Após a elucidação do gênero do discurso do documento, tomou-se o caso da "felicidade como bem patrimonial" como objeto de reflexão, uma vez que aparece na Carta como sendo o princípio máximo a ser garantido através da paisagem e enquanto bem patrimonial coletivo das Américas. Buscou-se, ainda, identificar características das Cartas nacionais e regionais já escritas no âmbito americano que nos denunciassem suas metodologias. Isso, pois ao se compreender o processo de criação das Cartas, entende-se quão comprometidas estão com a representação das singularidades e particularidades; quão comprometidas estão com a alteridade e com as diversas formas de conceber e relacionar com a paisagem. Resultados: A escolha do gênero discursivo não garante a vontade de servir como instrumento e há uma falta de precisão conceitual que abre a possibilidade de manipulação subjetiva e ideológica dos princípios declarados. $\mathrm{O}$ direito à felicidade como bem patrimonial coletivo das Américas é uma vontade transcendental, despreocupada com a realidade concreta que, por fim, não se legitima. Conclusão: Tal documento representa um avanço no caminho de pensar nossas paisagens de maneira coletiva. Mas no mesmo movimento, mostra-nos também a dificuldade de operacionalizar um projeto coletivo; a dificuldade de construir coletivamente metodologias que possibilitem representar a alteridade presente nos países e regiões que compõem as Américas. Os princípios nela declarados são muito mais expressão transcendental da vontade de alguns intelectuais, que uma expressão imanente e realmente concreta. Chama-se atenção, especialmente, para a necessidade de superação desse transcendentalismo que marcou a Construção de nossas Cartas nacionais, regionais e, consequentemente, de nossa Carta Continental da Paisagem; para a necessidade de abrir-nos em direção ao Outro. As realidades das Américas que são diversas, plurais, singulares, contraditórias ao serem tocadas pelos instrumentos desenvolvidos a partir dos princípios universalistas da Carta, certamente serão descaracterizadas por princípios descolados de sua realidade. Por tanto, a escolha do gênero discursivo não garantiu a vontade de servir como o instrumento que viabilizará a conquista do direito a felicidade como bem patrimonial coletivo das Américas.

Palavras-chave: Carta da Paisagem. Gênero do discurso. Bakhtin. Paisagem.

\section{ABSTRACT}

Introduction: The present work results from a dialogical and critical understading of the recently published Carta del Paisaje de las Américas where there is an attempt to find out the singularities of this paper compared to others once written in the Americas. This text, as a whole, addresses at which extent such document is an instrument, and by doing so, its existence as an instrument that grants the right to happiness as Americas' collective asset. Purpose: The present work aims at

\author{
Ítalo César de Moura Soeiro ${ }^{a}$ \\ Maite Hernández Alfonso ${ }^{a}$ \\ Joyce Caroline Gomes da Sllva ${ }^{b}$ \\ Diane Góis Cavalcanti Rodrigues ${ }^{\text {a }}$ \\ ${ }^{a}$ Universidade Federal de Pernambuco \\ (UFPE), Recife, PE, Brasil \\ ${ }^{\mathrm{b}}$ Faculdade de Ciências Humanas - \\ ESUDA (ESUDA), Recife, PE, Brasil
}

DOI: 10.12957/geouerj.2021.47417

Correpondência: fulano@gmail.com

Recebido em: 20 fev. 2021 Aceito em: 22 ago.2021 
claiming the Carta as an instrument that will grant the right to happiness as a collective asset of the Americas. Methods (Optional): To achieve the purpose, it was read all Cartas ever produced, whether regionally or nationally, in the Americas, in order to understand their discursive genre - supported by the diological language conception developed by Mikhail Bakhtin and his circle - whose document referred in this article belongs to. After elucidating the genre of the document's discourse, the case of "happiness as a asset" was taken as an object of reflection, since it is exposed in the Carta as the maximum principle to be granted through the landscape and as a collective asset of the Americas. We also focused on the identification of characteristics of both national and regional Cartas already written in the American scope which would unveil their methodologies. For this reason, when understanding the process of creating the Cartas, it is taken into account how committed they are to the representation of singularities and particularities; how committed they are to alterity and to the different ways of conceiving and relating to the landscape. Results: The choice of the discursive genre does not guarantee the longing for serving as an instrument and there is a lack of conceptual precision that opens up the possibility of manipulating specifications and ideological principles found on the document. The right to happiness as a collective asset in the Americas is a transcendental longing, detached from the concrete reality that, therefore, is not legitimate. Conclusión: This document represents an advance regarding the way we think about our landscapes collectively. But at the same time, it also shows us the difficulty of operationalizing a collective project as well as the trouble constructing methodologies collectively that enable to represent the otherness present in the countries and regions made up by the Americas. The principles stated are much more transcendental expression of some intellectuals' wish, than an immanent and really concrete expression. Attention is drawn, in particular, to the need to overcome this transcendentalism that highlighted the Construction of our National, Regional Cartas and, consequently, of our Continental Landscape Carta; to the need to open ourselves up to other individuals. The realities of the Americas, which are diverse, plural, singular, contradictory when brought out by the instruments developed based on the universal principles of the Carta, will certainly be uncharacterized by principles detached from their reality. Therefore, the choice of the discursive genre did not grant the longing to being used as an instrument that will enable the achievement of the right to happiness as a collective asset in the Americas.

Keywords: Landscape letter, Discursive genre, Bakhtin, Landscape.

\section{RESUMEN}

Introducción: Este artículo es el resultado de una comprensión dialógica y crítica de la recientemente publicada Carta del Paisaje de las Américas, y busca descubrir las características únicas de esta Carta en relación con otras Cartas del Paisaje escritas en América. El texto, en general, indaga en qué medida este documento es un instrumento $y$, de ser así, en qué medida es un instrumento que garantiza el derecho a la felicidad como bien patrimonial colectivo de las Américas. Objetivo: El objetivo de este artículo es interpelar la Carta como instrumento que garantizará el derecho a la felicidad como bien patrimonial colectivo en las Américas. Métodos (opcional): Para lograr el objetivo anterior, se realizó la lectura dialéctica de todas las Cartas de Paisaje producidas a nivel nacional y regional en las Américas para comprender este género discursivo - categoría anclada a la concepción dialógica del lenguaje desarrollada por Mikhail Bakhtin y su círculo - al cual pertenece el documento. Tras dilucidar el género discursivo del documento, se tomó como objeto de reflexión el caso de la "felicidad como bien patrimonial", ya que aparece en la Carta como el principio máximo a garantizar a través del paisaje y como bien patrimonial colectivo de las Américas. También se buscó identificar las diferentes metodologías utilizadas en las Cartas nacionales y regionales redactadas en el ámbito americano. Esto, porque al comprender el proceso de creación de las cartas, se entiende el nivel de compromiso con la representación de las singularidades y particularidades; con la alteridad y con las diferentes formas de concebir y relacionarse con el paisaje. Resultados: La elección del género discursivo en esta carta no garantiza la voluntad de servir de instrumento $y$, por otra parte, la falta de precisión conceptual abre la posibilidad de manipulación subjetiva e 
ideológica de los principios declarados. El derecho a la felicidad como bien patrimonial colectivo en las Américas es una voluntad trascendental, despreocupada de la realidad concreta y, en definitiva, no se legitima. Conclusión: La Carta del Paisaje de las Américas representa un avance en la forma de pensar colectivamente sobre nuestros paisajes, pero, igualmente también nos muestra la dificultad de operacionalizar un proyecto colectivo; la dificultad de construir colectivamente metodologías que permitan representar la alteridad presente en los países y regiones que conforman las Américas. Los principios en ella enunciados son una expresión mucho más trascendental de la voluntad de algunos intelectuales, que una expresión inmanente y realmente concreta. Se llama la atención, en particular, sobre la necesidad de superar este trascendentalismo que marcó la Construcción de nuestras Cartas Nacionales, Regionales y, en consecuencia, de nuestra Carta Continental del Paisaje; e igualmente, a la necesidad de abrirnos al Otro. Las realidades de las Américas, que son diversas, plurales, singulares, contradictorias cuando son tocados por los instrumentos desarrollados con base en los principios universalistas de la Carta, ciertamente serán des-caracterizadas por principios desvinculados de su realidad. Por tanto, la elección del género discursivo no garantizó la voluntad de servir como instrumento que posibilite la conquista del derecho a la felicidad como bien patrimonial colectivo en las Américas.

Palabras-clave: Carta del paisaje, Género discursivo, Bakhtin, Paisaje. 


\section{INTRODUÇÃO}

O presente artigo é resultado de uma compreensão dialógica e crítica da recém-publicada Carta del Paisaje de las Américas. Toca acrescentar que toda crítica é fruto de uma compreensão e tenha ela a dimensão que tiver, implica uma responsividade (BAKHTIN, 2000). Nesse sentido, ao ler e compreender dita Carta, adotou-se, ao mesmo tempo, em relação a ela, uma atitude responsiva ativa. Deve-se acrescentar também que toda compreensão é carregada de resposta. Isso esclarece o fato de que a compreensão passiva é tãosomente parte do processo total de compreensão. $O$ todo é a compreensão responsiva, que se expressa num ato real e concreto de resposta. Compreender, portanto, é aqui entendido como participar de um diálogo com o texto analisado, mas também, com seu destinatário, uma vez que a compreensão não se realiza sem que adentremos numa situação de comunicação (FIORIN, 2006). Na medida em que nos colocamos como participantes de um diálogo que se estabelece em torno da Carta, a compreensão desse documento não é estritamente subjetiva, mas, pelo contrário, é inevitavelmente social. O presente artigo é, assim, a materialização de nossa compreensão responsiva ativa da Carta.

Antes de aclarar, porém, por quais caminhos nosso diálogo crítico com a Carta seguirá e estará arrimado, cabe tecer breves comentários acerca da historicidade em que a dita Carta está inserida. Isso, pois acreditamos na premissa metodológica que nos direciona para a necessidade de não encarar um documento como um sistema fechado. Opta-se, aqui, pela leitura da totalidade do documento. A partir daí, além de inseri-la em sua série histórica, procuramos investigar as características singulares desta Carta em relação à outras Cartas da Paisagem já redigidas nas Américas. Nesse sentido, não trataremos a Carta e sua discursividade apenas por sua condição formal e externa, por seu aparente imediato. Pelo contrário. É preciso alcançar sua especificidade, cabe destacar, não dedutível se tomada isoladamente. Só se alcança tal profundidade analítica, se considerarmos o todo orgânico do enunciado e o projeto discursivo do enunciador.

Dando início à narrativa da historicidade do documento em epígrafe neste estudo, toca aclarar que, no quadragésimo sétimo Congresso Internacional de Arquitetura de Paisagem da Federação Internacional de Arquitetos Paisagistas (IFLA), que aconteceu em Suzhou, China, em 2010, os países membros dessa organização assumiram o compromisso de desenvolver Cartas Nacionais da Paisagem, como parte do processo de elaboração de uma Carta e eventualmente uma Convenção da Paisagem a nível global. A Carta Global estaria respaldada pela Organização das Nações Unidas para a Educação, a Ciência e a Cultura (UNESCO) e, dentro de seus conteúdos, destacar-se-ia o tema do direito à paisagem como bem coletivo. Segundo relatado na Carta, desde o início, ficou claro que a Carta Global é de certa complexidade, em virtude das diferentes acepções de paisagem próprias da ampla diversidade geográfica, histórica, social, ambiental e cultural de quem as definiriam universalmente. 
A partir do encontro de Suzhou, as Cartas Nacionais da Paisagem passaram a ser produzidas, organizando-se, em alguns casos, em nível regional ou continental, até abarcar os cinco blocos mundiais da IFLA. No caso das Américas, o pioneirismo ficou por parte da Colômbia, país que engendrou um movimento transnacional denominado La Iniciativa Latinoamericana del Paisaje (LALI), que impulsionou a redação da Carta Latinoamericana del Paisaje, cuja concepção ao evoluir em direção à paisagem do continente em sua totalidade, chega a ser designada de Carta del Paisaje de las Américas.

Dos trinta e cinco países que compreendem o continente americano, dezenove estão associadas à IFLA. Dezesseis deles redigiram suas Cartas Nacionais da Paisagem. A maioria das Cartas promove a proteção, o planejamento e a gestão sustentável das paisagens. Algumas, de forma explícita, aderiram aos fundamentos presentes no Convênio Europeu da Paisagem (European Landscape ConvencioN, 2000). Ora num movimento de cópia ipsis litteris e, logo, numa lógica transcendental, ora como fruto de um trabalho realmente engajado e baseado na concreticidade dos recortes espaciais em questão.

Nesse sentido, no processo de análise crítica da Carta, ao qual nos propomos aqui, deve-se ter em conta que o dito documento se situa enquanto Carta da Paisagem - gênero discursivo que, por necessidade metodológica, será caracterizado mais adiante nesse estudo -, redigida numa escala continental e que tem como objetivo "ser un instrumento de planificación y acción que garantiza el derecho a la felicidad como un bien colectivo patrimonial. [...]" (CARTA DEL PAISAJE DE LAS AMÉRICAS, 2018, p.3). Ou seja, que tem o compromisso de realizar uma síntese das demais Cartas da Paisagem já redigidas no contexto americano e servir de base para a construção da Carta Global da Paisagem.

O objetivo dessa rápida digressão foi apontar para a lógica interna da Carta. Uma digressão necessária e movida pelo princípio e convicção metodológica de que toda a produção cultural humana se elabora a partir de uma situação histórica e geográfica específica. Comprometer-se com tal situação de produção é se comprometer, num mesmo movimento, com os sentidos produzidos pelo projeto discursivo dos autores.

O presente texto, como dito antes, vem tecer uma recepção crítica da Carta. Neste, portanto, indagaremos em que medida o dito documento se trata de um instrumento e, se o for, em que medida é um instrumento que garante o direito à felicidade como bem patrimonial coletivo das Américas. Isso, pois, a priori, supomos que o gênero discursivo Carta da Paisagem não ultrapassa a condição de declaração de princípios. Assim, postula-se que a Carta del Paisaje de las Américas, assim como outras Cartas já redigidas nas Américas, não é um instrumento em si, mas um documento que declara princípios éticos fundamentais em volta da paisagem. Esses princípios, por sua vez, que embasariam a construção de instrumentos de gestão, planejamento e intervenção nas paisagens. 
Em sendo assim, indaga-se: em que medida o gênero discursivo da Carta del Paisaje de las Américas permite concretizar a vontade discursiva de servir como instrumento de planejamento e gestão que garantirá o direito à felicidade como bem patrimonial coletivo das Américas? Responder a essa questão é tecer uma leitura crítica de um documento que se lança como síntese dialética, como "unidade na diversidade" das demais Cartas já produzidas em âmbito nacional e regional nas Américas. Assim, espera-se auxiliar na apreciação mais cuidadosa dos objetivos e da vontade discursiva da dita Carta. Para tanto, consideramos necessário cultivar o descolamento da imediaticidade do documento; cultivar, em nossa leitura dialética, o ato epistemológico consciente da negação dessas aparências imediatas; cultivar a condição ativa da consciência para que essa se coloque de maneira responsiva diante da Carta e de seu gênero discursivo; e, por fim, cultivar a atitude crítica.

Prezando pelo bom entendimento dos pontos de partida de nossa crítica, cabe destacar que se partiu do seguinte conjunto de hipóteses: A Carta del Paisaje de las Américas representa um avanço na forma de conceber a paisagem coletivamente, porém não acreditamos que esta garantirá o direito à felicidade como bem patrimonial coletivo das Américas. Não, pois não se trata de um instrumento, mas de uma declaração de princípios éticos fundamentais vinculados à paisagem. Nesse sentido, a Carta declara princípios que devem nortear as intervenções nas paisagens das Américas; que devem nortear a construção de verdadeiros instrumentos na pequena escala e não de maneira generalista e universalista como proposto pelo projeto que culmina na construção desse dito documento. Isso, pois um instrumento pensado na escala continental, universalista e que beira, constantemente, o reducionismo homogeneizador - ainda que se coloque como unidade na diversidade -, não logra intervir numa fração de território - cabe incluir, de condições ontologicamente diversas que é o continente americano - de maneira a evitar a supressão das singularidades e particularidades inerentes às paisagens das Américas. Mesmo diante dessa conjuntura, a Carta não tem como garantir que os instrumentos específicos que serão desenvolvidos a partir dos princípios declarados em seu corpo sustentem a construção cultural e coletiva de um sistema de valores éticos em volta da paisagem e que nos garanta a felicidade como bem patrimonial coletivo. Nesse sentido, não tem como garantir por um somatório de fatores, são eles:

- A escolha do gênero discursivo não garante a vontade discursiva de servir como instrumento;

- A falta de precisão conceitual ou mesmo ausência de definição de alguns conceitos basilares abre a possibilidade de uso subjetivo e ideológico dos princípios declarados na Carta por parte dos agentes públicos e privados de modificação da paisagem;

- A transcendentalidade dos princípios declarados marcada no processo construtivo do documento. Os princípios foram construídos a partir de um processo de síntese das demais 
Cartas da Paisagem já construídas no continente americano. O problema não reside exatamente nessa condição metodológica da Carta, mas no fato de que algumas das demais Cartas Nacionais e Regionais que serviram de base para sua construção nem sempre foram construídas de maneira participativa e preocupada com a representação das singularidades e particularidades das paisagens que compõem o todo da América - a existência de cópia entre as Cartas nos fez postular tal hipótese.

- A ilegitimidade, por fim, da felicidade enquanto bem patrimonial coletivo.

Fica evidente, portanto, que o objetivo do presente artigo é interpelar a Carta enquanto instrumento que garantirá o direito à felicidade como bem patrimonial coletivo das Américas. Para tanto, recorreu-se a leitura dialética de todas as Cartas da Paisagem já produzidas em âmbito nacional e regional nas Américas a fim de compreender tal gênero discursivo (BAKHTIN, 2000) ao qual pertence o documento em epígrafe neste ensaio. Isso, pois tendo bem interpretado seu gênero logo nos possibilitou interpelar o documento de maneira mais coerente com as limitações e possibilidades que o gênero impõe. Após a elucidação do gênero do discurso do documento, tomou-se o caso da "felicidade como bem patrimonial" como objeto de reflexão, uma vez que aparece na Carta como sendo o princípio máximo a ser garantido através da paisagem e enquanto bem patrimonial coletivo das Américas. Buscou-se, ainda, identificar características das Cartas nacionais e regionais já escritas no âmbito americano que nos denunciassem suas metodologias. Isso, pois ao se compreender o processo de criação das Cartas, entende-se quão comprometidas estão com a representação das singularidades e particularidades; quão comprometidas estão com a alteridade e com as diversas formas de conceber e relacionar com a paisagem.

Para tanto, visando à realização da discussão ora proposta, este texto foi estruturado da seguinte forma: na próxima seção, A Carta del Paisaje de las Américas enquanto gênero discursivo: entre declaração de princípios e instrumento de gestão e planejamento, o texto praticou uma imersão nas Cartas da Paisagem através das categorias bakhtinianas em volta do Gênero do Discurso (enunciado, tema, estilo, forma composicional etc.); na terceira seção, Felicidade como bem patrimonial coletivo das Américas: uma vontade transcendental ou uma vontade concreta?, trouxemos à tona alguns aspectos metodológicos das Cartas da Paisagem que podem, por sua vez, demonstrar fraquezas a serem revisadas no documento aqui analisado; fraquezas que podem atrapalhar seu objetivo de garantir o direito à felicidade como bem patrimonial das Américas; e, por fim, realizam-se algumas considerações a fim de responder questões abertas no texto e iluminar novas interrogantes a partir do que se conseguiu inferir nesta crítica dialógica. 


\section{A CARTA DEL PAISAJE de LAS AMÉRICAS ENQUANTO GÊNERO DISCURSIVO: ENTRE DECLARAÇÃO DE} PRINCÍPIOS E INSTRUMENTO DE GESTÃO E PLANEJAMENTO

Tento em vista que quase a totalidade das Cartas Nacionais e Regionais da Paisagem desenvolvidas por países das Américas e outras Cartas com intenção discursiva parecida afirmam, de maneira explicita, serem declarações de princípios, indaga-se: a Carta del Paisaje de las Américas é de fato um instrumento de planejamento e gestão? Essa é a pergunta que norteia a busca desse primeiro tópico. Nesse sentido, o primeiro movimento metodológico desse artigo é esclarecer o gênero discursivo do documento. Seria um instrumento de planejamento e gestão? Seria, como as demais Cartas da Paisagem, uma declaração de princípios? A vontade discursiva expressa no ato de autonomear-se de instrumento de planejamento e gestão se concretiza no gênero utilizado? A Carta se lança como instrumento, mas o tema, a forma composicional e o estilo enquadram o documento como tal? São perguntas como essas que pretendemos elucidar nesse primeiro tópico.

A maioria dos pesquisadores que se utilizam da categoria gênero, especialmente no que se refere à análise e produção de textos, em algum momento se deparam com a noção bakhtiniana (Brait e Pistori, 2012). Em geral, segundo alertam as autoras, a maioria desses pesquisadores acaba entendendo gênero do discurso como uma "fórmula mágica, reduzida exclusivamente a três elementos: forma de composição, conteúdo temático e estilo, concluindo que, uma vez aplicada, essa receita dará conta da compreensão e ensino de gêneros e, consequentemente, da leitura e produção de textos." (Brait e Pistori, 2012, p.374). Pesquisadores que pelo motivo ora exposto negligenciam o real objeto de reflexão ao qual os gêneros do discurso em Bakhtin (1997; 2000; 2008) se referem, a saber: o enunciado como um todo orgânico, que se (re)produz em espaço e tempo reais, implicando auditório, recepção responsiva e dupla orientação na realidade. Dupla orientação essa que se deve, em primeiro lugar, ao fato da Carta se orientar para um determinado auditório com condições específicas de recepção; e, em segundo lugar, ao fato da Carta se orientar na vida por sua situação concreta e não reiterável. Assim, pode-se dizer que a Carta participa da vida e entra em contato com os diferentes aspectos da realidade que a circunda. Se concretiza como algo produzido e lido em um determinado tempo e lugar e em determinadas circunstâncias. Ocupa, portanto, um lugar definido na vida social. Cabe destacar que, sem essa compreensão, corre-se o risco de deixar de lado a exterioridade constitutiva da Carta, relacionada, por exemplo, às esferas ideológicas, podendo significar o abandono da totalidade do enunciado, de sua dupla orientação.

É buscando esquivar dos riscos metodológicos iluminados por Brait e Pistori (2012) que partiremos da noção Bakhitiniana de gênero do discurso sem a reduzir às suas três categorias já tão popularizadas (estilo, forma composicional e tema) para interpelar a Carta - não reduziremos, mas utilizaremos as ditas categorias. Nesse sentido, cabe entender que nos comunicamos, sempre, por meio de gêneros no interior de uma dada 
esfera da atividade humana; que os gêneros não se reduzem às produções literárias, dizendo respeito, também, à linguagem cotidiana em sua extensa variedade. Variedade essa que se deve a multiplicidade de experiências individuais e coletivas, vivenciadas numa sociedade, num tempo e numa cultura. Nas palavras de Bakhtin (2000, p.283): "Se os gêneros do discurso não existissem e nós não os dominássemos, se tivéssemos que criá-los pela primeira vez no processo do discurso, de construir livremente e pela primeira vez cada enunciado, a comunicação discursiva seria impossível". Fica evidente, assim, que a maneira como esse teórico concebe o gênero do discurso nos direciona para a ideia de que os gêneros governam os discursos interiores e exteriores. Conforme comentam Brait e Pistori (2012, p.397-398), "São, portanto, formas de pensar, constituindo um modo específico de visualizar e representar uma dada realidade, não se reduzindo a uma coleção de dispositivos nem a um modo de combinar elementos linguísticos.".

A primeira consideração a se fazer, portanto, é que as Cartas da Paisagem, além de uma forma estrutural composta por elementos linguísticos específicos, são uma maneira particular de visualizar e representar uma dada realidade - representar um território -, cabe destacar, com uma dada intenção discursiva. Nesse sentido, para elucidar os elementos linguísticos e metalinguísticos que estão envolvidos na caracterização do gênero Carta da Paisagem, portanto, faz-se imperativo considerar a tradição em que o dito gênero se insere, apontando que o mesmo se liga a uma memória genérica, que necessita ser identificada e compreendida, implicando num estudo diacrônico e sincrônico do documento. Ou seja, a Carta não será aqui pensada fora da dimensão espaço-temporal, pois todas as formas de representação que nela estão abrigadas são igualmente orientadas pelo espaço-tempo. O gênero Carta da Paisagem adquire, assim, uma dimensão cultural e passa a ser expressão de um grande tempo, enquanto memória criativa.

Munindo-se dessa chave de interpretação dos gêneros do discurso, cabe destacar que a Carta tem uma historicidade - não é a primeira Carta da Paisagem - e que não pode ser interpretada isoladamente. Nesse sentido, deve-se entender que as Cartas da Paisagem são fruto de uma historicidade - essa já exposta na introdução desse texto. Não é a primeira vez que esse gênero está sendo utilizado e, com toda certeza, não será a última. Destarte, pode-se dizer que os autores do documento aqui analisado escolheram o gênero Carta da Paisagem acreditando que seu projeto discursivo e suas intenções seriam contempladas.

Assim sendo, para caracterizar e compreender o gênero Carta da Paisagem, leituras interpretativas e dialéticas foram realizadas das demais Cartas já desenvolvidas em âmbito nacional e regional nas Américas e logo se identificou que as mesmas se colocam e autodenominam declarações de princípios, a saber: as Cartas da Paisagem venezuelana, boliviana, brasileira, mexicana, uruguaia, colombiana, costa-riquense e da América Central e Caribe, todas assumem ser declarações de princípios:

Una carta del paisaje es una declaración de principios éticos para promover el reconocimiento, la valoración, la protección, la gestión y la planificación sustentable de los paisajes de cada país, mediante la adopción de instrumentos legales (leyes, acuerdos, etc.) que reconozcan la diversidad y los valores 
locales, regionales y nacionales, así como los principios y procesos pertinentes para salvaguardar los recursos del paisaje. (Carta Venezolona del Paisaje, 2014, p.6)

La IFLA, Federación Internacional de Arquitectos Paisajistas, ha estado promoviendo desde el año 2006 la idea de una Convención Global del Paisaje. América Latina se ha sumado a esta iniciativa y por ende Bolivia a través de SAPEMA y los diferentes actores sociales. Las Cartas del Paisaje se caracterizan por ser una declaración de principios éticos, fundamentales para promover el reconocimiento, valoración, protección, gestión y planificación sostenible de los paisajes en cada país, la carta se inspira en la Convención Internacional del Paisaje (ILC) promovido por la IFLA. (Carta Boliviana del Paisaje, 2016, p.3)

En esta Carta declaramos los principios fundamentales para la protección, revalorización, y reconocimiento del paisaje, considerando su diversidad y su calidad de bien público [...].(Carta Mexicana del Paisaje, 2012, p.8)

La Carta Colombiana del paisaje es una declaración de principios éticos fundamentales para promover el reconocimiento, la valoración, la protección, la gestión y la planificación sostenible de los paisajes colombianos, mediante la adopción de convenciones (leyes, acuerdos) de paisaje que reconozcan la diversidad y los valores locales, así como los principios y los procesos pertinentes para salvaguardar los recursos del paisaje. (Carta Colombiana del Paisaje, 2010, p.2)

Uma Carta da Paisagem é uma declaração de princípios éticos ( que envolvem a ecologia, a justiça socia e as políticas culturais e econômicas de desenvolvimento) para promover o reconhecimento, avaliação, proteção, gestão e planejamento sustentável de paisagens em cada país, através da adoção de convenções (leis, acordos) que reconhecem a diversidade paisagística e os valores locais, regionais e nacionais, bem como os princípios e processos relevantes para salvaguardar os recursos da paisagem. (Carta Brasileira da Paisagem, 2012, p.10)

Las Cartas de Paisaje, que en esa instancia fueron solicitadas a cada Asociación Gremial afiliada a IFLA para participar en esta iniciativa, son esencialmente declaraciones de principios fundamentales alrededor de los valores que el paisaje adquiere para todas culturas. (Carta Chilena del Paisaje, 2011, p.5)

Esta Carta es un manifiesto realizado por los miembros de la agrupación multinacional denominada Asociación de Paisajismo de Centroamérica y el Caribe APAC quienes como miembros de IFLA, decidimos realizar esta declaración de principios éticos fundamentales y postulados técnicos de excelencia con el propósito de crear conciencia y difundir la necesidad del reconocimiento del paisaje como un bien único e intangible que debe ser protegido, valorizado y desarrollado a través de la planificación, el diseño y la gestión sostenible de la Arquitectura de Paisaje en los países de Centroamérica y el Caribe. (Carta del Paisaje de Centroamérica y Caribe, 2016, p.3)

No que toca à Carta, esta não menciona em nenhum momento do documento que se trata de uma declaração de princípios, mas, pelo contrário, lança-se, a contrapelo dos demais documentos, como um instrumento, como pode ser notado na passagem já citada desse mesmo artigo: "[...] un rasgo definitorio de la Carta del Paisaje de las Américas: ser un instrumento de planificación y acción que garantiza el derecho a la felicidad como un bien colectivo patrimonial. [...]" [grifo nosso] (CARTA DEL PAISAJE DE LAS AMÉRICAS, 2018, p.3).

É nesse momento que questionaremos o sentido de "instrumento" presente no documento; é nesse momento que o sentido de "instrumento" presente na Carta se choca com o apresentado por Abbagnano (2007), que, por sua vez, entende instrumento como meio capaz de obter um resultado em qualquer campo da atividade humana. Assim, instrumento seria um meio para transformação objetiva da realidade. Entendendo, por outra parte, 'meio" como tudo que possibilita alcançar um fim, cumprir um objetivo ou realizar um projeto, logo a contradição da Carta enquanto instrumento se faz notória. Sob essa perspectiva, 
indaga-se: a Carta é constituída enquanto um meio que visa um fim? Respondemos que sim, pois a escolha de um gênero discursivo sempre é produto de uma finalidade discursiva. Porém, se pensarmos essa afirmação no seu sentido mais básico, isto é, se a Carta é um meio para um fim, então essa simples constatação abre o domínio para um questionamento mais essencial: um meio para que fim?

O fato da finalidade da Carta ser obviamente correta não significa, no entanto, que esse fim seja a garantia do direito à felicidade como bem patrimonial coletivo das Américas. Ou seja, não significa que seja o instrumento que garantirá isso. Indaga-se, também, se o documento não seria uma declaração de princípios éticos fundamentais que embasaria a construção dos verdadeiros instrumentos que, por sua vez, permitiriam objetivar a vontade de felicidade já citada. E, ainda, como garantir que a utilização dos princípios declarados na Carta guiará sempre para a garantia da felicidade? Em que medida as realidades das Américas que são diversas, plurais, singulares, contraditórias e, cabe destacar, com formas de conceber, sentir e relacionar com a paisagem igualmente diversas, plurais, singulares e contraditórias, ao serem tocadas pelos instrumentos desenvolvidos a partir dos princípios universalistas da Carta, não seriam descaracterizadas por princípios que podem estar descolados de sua realidade?

Diante dessa desconstrução do sentido de "instrumento" na Carta e entendendo que seu fim declarado é a garantia do direito à felicidade como bem patrimonial coletivo das Américas, inclinamo-nos a acreditar que a Carta não é um instrumento de fato para esse fim. Se adicionarmos a nossa desconstrução do sentido de "instrumento", o fato de que documentos com tema, forma composicional e estilo similares - pensemos nos casos das demais Cartas citadas acima - se autodenominam pertencer ao gênero discursivo declaração de princípios, logo pode-se fechar a questão. Tendo em vista que a finalidade da Carta é declarar princípios éticos fundamentais que, por sua vez, embasarão a construção de instrumentos de intervenção nas paisagens americanas, pode-se inferir que a Carta não se trata de um instrumento, mas de uma declaração de princípios e será sob esta condição que a interpelaremos no decorrer do ensaio.

Mas o que nos abre de chaves interpretativas identificar que a dita Carta está dentro do gênero declaração de princípios? Partindo de uma abordagem dialética, o caminho metodológico mais intuitivo que a consciência nos direciona é a contraposição dos objetivos declarados no documento às possibilidades e limites impostos pelo gênero discursivo utilizado. Nesse sentido, a contraposição da condição de declaração de princípios à vontade discursiva da garantia do direito à felicidade como bem patrimonial coletiva das Américas.

Segundo Bakhtin (2000, p.283), "a vontade discursiva do falante só se manifesta na escolha de um determinado gênero [...]". Ou seja, a intenção do autor se realiza em função de uma escolha efetuada dentre as formas relativamente estáveis dos enunciados, de um gênero do discurso. Nesse sentido, pergunta-se: por que os autores da Carta escolheram o gênero declaração de princípios a uma monção, um manifesto, etc? 
Que vontade discursiva está por trás de uma declaração de princípios? Essas vontades estão compatíveis com os objetivos do documento? Como sabemos, existe uma vontade declarada de servir como instrumento, mas o gênero do discurso utilizado possibilita a realização dessa vontade?

Para responder às questões supracitadas, necessitamos elucidar quais são essas possibilidades e limites impostos pelo gênero Carta da Paisagem. Nesse sentido, como já anunciado antes, consideraremos as Cartas da Paisagem a partir da concepção de gênero do discurso de Bakhtin (2000) e utilizaremos das três categorias propostas pelo autor para definir ou descrever um gênero, a lembrar: tema, forma composicional e estilo.

Na obra Bakhtiniana, o tema não pode ser confundido com "assunto". O tema é o domínio de sentido do enunciado como um todo a partir de uma situação de enunciação concreta que envolve aspectos históricos, culturais e sociais. "O tema da enunciação é na verdade, assim como a própria enunciação, individual e não reiterável. Ele se apresenta como a expressão de uma situação histórica concreta que deu origem a enunciação." (Bakhtin, 1979, p. 114). Assim, o sujeito, ao enunciar algo, não recorre unicamente ao sistema linguístico, mas a outras enunciações (a outras Cartas), adequando seu discurso a seus objetivos comunicativos e a seus interlocutores. Enfim, constrói um sentido particular e não reiterável para aquilo que diz, constituindo, dessa forma, um tema.

Diante de tal noção, pode-se dizer que as Cartas da Paisagem são documentos de carácter público que contêm um compromisso explícito a favor da paisagem enquanto declaração de princípios éticos fundamentais. Em tal gênero, as partes assinantes se comprometem ante a sociedade a fazer parte de um projeto coletivo e a trabalhar em consequência disso para alcançar os compromissos firmados, desenvolvendo as estratégias, instrumentos, medidas e ações a partir dos princípios estabelecidos e declarados.

No tocante à enunciação concreta em que está inserida a Carta, conforme já aclarado na breve contextualização histórica presente em nossa introdução, essa se situa enquanto apogeu do projeto de construção de uma Carta Continental da Paisagem e que, mais tarde, "[...] contribuirá a la construcción del Convenio Global del Paisaje, respondiendo por el Continente Americano como la quinta pieza del 'rompecabezas' planetário." (CARTA DEL PAISAJE DE LAS AMÉRICAS, 2018, p.10). Um documento único, pois tem uma função única, um sentido único e, logo, um tema também único e não reiterável. Toca destacar que igualmente únicos são os temas das demais Cartas Nacionais e Regionais, uma vez que cada uma se propõe a representar um recorte espacial específico e único, num dado tempo histórico não repetível.

Para evidenciar a dupla orientação do documento, toca destacar também que a Carta tem um auditório concreto. Portanto, direciona-se aos "arquitectos del paisaje para que, conscientemente, incorporen los valores de las Américas, tangibles e intangibles [...], en sus proyectos de paisajes futuros." (CARTA DEL PAISAJE DE LAS AMÉRICAS, 2018, p.9). Além dos arquitetos paisagistas, direciona-se também a "todos los demás 
profesionales, de diversas áreas del conocimiento, así como las comunidades que trabajan en la gestión y conservación, que tienen el paisaje como objeto e interés de sus intervenciones." (CARTA DEL PAISAJE DE LAS AMÉRICAS, 2018, p.9). Portanto, assume-se que a consequência progressiva dos objetivos estabelecidos na Carta deve contribuir à consolidação do direito à felicidade como bem patrimonial coletivo das Américas. Ademais, tanto o diagnóstico como os objetivos e os princípios que se elaboraram mediante a Carta proporcionam dados específicos que poderão ser considerados nos instrumentos e processos de planejamento territorial e urbanístico empreendidos pelos agentes produtores do espaço que incidem sobre a paisagem.

A forma composicional, por sua vez, é determinada pelo projeto enunciativo do locutor, não se confunde com uma forma rígida, porque pode se modificar de acordo com as alterações dos projetos enunciativos. Trata-se da maneira como o gênero mobiliza um texto, a estrutura textual do gênero. Nesse sentido, ainda que com variações particulares, temos como forma Composicional das Cartas da Paisagem a seguinte estrutura:

- Preâmbulo: a elaboração de um diagnóstico das dinâmicas da paisagem no âmbito territorial ao qual se refere a Carta. $\mathrm{O}$ diagnóstico das tendências deve estar dirigido a detectar os processos que se produzem na paisagem objeto da Carta e definir as variáveis e agentes associados às ditas dinâmicas, determinando os riscos que comprometem a manutenção da qualidade paisagística.

- Declaração de princípios fundamentais: uma vez elaborado o diagnóstico, a equipe redatora da Carta começa a definir princípios fundamentais, considerando os aportes, interesses e pontos de vista manifestados pelos distintos agentes - isso quando são fruto de trabalhos realmente comprometidos com a escuta e representação das alteridades, particularidades e singularidades de um território. O propósito da definição de princípios e objetivos é o de chegar a estabelecer um nível máximo de consenso na definição desses. Em suma, trata-se do momento da definição de princípios que deveriam nortear as ações no âmbito territorial ao qual se refere a Carta da Paisagem. Os ditos princípios devem ser coerentes com os objetivos de qualidade estabelecidos para cada uma das unidades de paisagem definidas.

- Assinatura da Carta: uma vez superadas as duas fases do processo de elaboração da Carta da Paisagem, é necessário formular um documento que constitua o pacto para a proteção, ordenamento, gestão e melhora da paisagem, redigido de modo que possa ser assinado pela maior parte dos agentes públicos e privados implicados diretamente na promoção da Carta da Paisagem. 
- Glossário: lista alfabética com as definições dos termos e conceitos que os autores julgam fundamentais ao entendimento mais preciso dos princípios e objetivos declarados nas Cartas. A tradição genérica roga que o glossário apareça no final das Cartas, porém, é comum encontrar outras formatações ou mesmo outras nomenclaturas, tais como: definições, referencial teórico, conceitos etc. Também é possível encontrar, ainda que em menor número, Cartas que se utilizam de citações no formato autor-data e referência, tal qual utilizado em gêneros científicos.

Deve-se notar, porém, que na forma composicional das Cartas da Paisagem, ainda que sejam escritas ao menos em nosso universo analisado - por acadêmicos e intelectuais e apresentem, por isso, marcas explícitas de gêneros científicos, não é característico desse gênero a expressão de seus percursos metodológicos. Ou seja, não é comum destinar espaço nas Cartas para expressar os caminhos metodológicos que guiaram a definição dos princípios. Tal fato nos permite entender a razão para que apenas uma das dezesseis Cartas da Paisagem já redigidas no âmbito do continente americano tenha nos oferecido seus aspectos metodológicos de maneira explícita.

A noção de estilo, por fim, apreende a ideia bakhtiniana de "[...] expressividade [que] aparece como uma particularidade constitutiva do enunciado [...]" (Bakhtin, 1997, p.315); ou de "[...] expressividade padrão de um gênero [...]" (Bakhtin, 1997, p.314). Sabendo disso, fica evidente que o estatuto que Bakhtin confere ao estilo manifesta o reconhecimento de que existem padrões sociais de uso dos recursos linguísticos, que possibilitam relacionar de maneira estável cada gênero com seu estilo. Por outra parte, Bakhtin assinala a possibilidade de quebra desses padrões nos eventos discursivos particulares e distingue "estilo do gênero" e "estilo individual" para apontar a dessemelhança entre o tratamento do estilo nos gêneros e nos enunciados. O estilo, assim, é o aspecto do gênero mais ligado à sua mutabilidade; é ao mesmo tempo expressão da relação discursiva típica do gênero e expressão pessoal dos autores no âmbito do gênero. Sabendo disso, indaga-se: quais as marcas de expressividade que denunciam as singularidades mais salientes da Carta del Paisaje de las Américas?

É imprescindível não perder de vista que a análise de questões estilísticas não remete ao "quê" o autor diz, mas a "como ele diz" (Possenti, 2001). Nesse sentido, talvez por ser um gênero muito marcado pelos gêneros de gênese científica e, logo, por uma intergenericidade constitutiva, a Carta, seguindo as forças centrípetas do estilo do gênero, remete a um intuito discursivo habituado ao tom de autoridade. Como expressividade, o estilo do gênero vincula-se à dominância da lógica implicativa - x, logo y - (Discini, 2012), conduzindo, assim, à minimização de sentidos outros que possam subverter ideologicamente os princípios declarados. 
Após a imersão que acabamos de realizar, fica evidente que a situação dá forma à enunciação; que o centro organizador de toda enunciação está no meio social que envolve o locutor. Como argumenta Bakhtin, "A situação e os participantes mais imediatos determinam a forma e o estilo ocasionais da enunciação. Os estratos mais profundos da sua estrutura são determinados pelas pressões sociais mais substanciais e duráveis a que está submetido o locutor." (Bakhtin, 1979, p.99).

\section{A FELICIDADE COMO BEM PATRIMONIAL COLETIVO DAS AMÉRICAS: UMA VONTADE TRANSCENDENTAL OU UMA VONTADE CONCRETA?}

Através das categorias bakhtinianas em volta do gênero do discurso, conseguiu-se iluminar a dupla orientação na realidade da Carta del Paisaje de las Américas. Partindo desse entendimento permitido por tais categorias, refletiremos agora sobre o processo de produção do documento. Sobretudo, buscaremos, no estudo desse processo, identificar como se chegou a definir a felicidade como vontade coletiva e patrimonial das Américas. Uma escolha retirada da realidade concreta ou de realidades transcendentais e alijadas dessa? Nesse sentido, vê-se como necessário questionar os métodos utilizados pelas Cartas nacionais e regionais da paisagem já produzidas nas Américas, uma vez que foi, sobretudo, através do estudo das mesmas que a Carta del Paisaje de las Américas foi construída. Utilizam de métodos participativos? Os métodos utilizados garantem a representação das singularidades e particularidades das formas de conceber e relacionar com as paisagens americanas? Se a Carta del Paisaje de las Américas procura ser uma síntese das demais Cartas Nacionais e Regionais já produzidas no continente americano, seria possível supor que o objetivo de garantir o direito à felicidade como bem patrimonial coletivo é um propósito comum em diversas zonas do continente? Foi uma decisão coletiva e participativa a que determinou a adoção desse objetivo? O que é um bem patrimonial coletivo? Como se define um bem patrimonial coletivo? A Carta del Paisaje de las Américas segue algum método coerente com a definição?

Como aclarado no tópico anterior, o gênero Carta da Paisagem não impõe a descrição metodológica do processo de construção dos objetivos e definição dos princípios declarados. Tal fato dificulta bastante a análise e problematização proposta nesse tópico. Para tanto, a investigação ora sugerida estará arrimada na problematização do processo de definição da felicidade como bem patrimonial coletivo diante de três fatos que denunciam aspectos metodológicos das Cartas, a saber: apenas três das dezesseis Cartas já produzidas nas Américas citam diretamente a "felicidade"; uma Carta Regional "construiu" todos os seus princípios através da cópia dos princípios de uma Carta Nacional; e, por fim, a única Carta que declara seus procedimentos metodológicos demonstra aspectos claramente transcendentais e em nada participativos. 
Se vamos buscar os aspectos metodológicos em volta da definição da felicidade como bem patrimonial coletivo, antes de mergulharmos nas Cartas procurando identificar tais aspectos, deve-se refletir rapidamente sobre a própria ideia de bem patrimonial coletivo. Isso, pois tal reflexão nos direciona a uma das críticas mais emergentes em nossa análise, essa vinculada à falta de precisão conceitual do documento; melhor dito, a inexistência, no corpo da Carta, de uma conceituação para bem patrimonial coletivo e, também, cabe destacar, para outras noções igualmente basilares. Ao analisar outros documentos com tema, forma composicional e estilo semelhantes, compreendemos que a extensão média desse gênero discursivo, Carta da Paisagem, é relativamente pequena e não permite argumentações muito longas, nem um preciosismo teórico - talvez por isso o uso dos glossários. Por outro lado, deve-se concordar que a carência de precisão conceitual objetiva abre a possibilidade de manipulação subjetiva e ideológica dos princípios declarados; abre a possibilidade de se desviar da finalidade objetivada pelo documento, isso é, da garantia do direito à felicidade como bem patrimonial coletivo. Pode-se inferir, assim, que a escolha do gênero impõe essa limitação e gera tal fragilidade no documento. A fragilidade reside exatamente no seguinte processo: os projetos e instrumentos de intervenção e gestão que serão construídos a partir dos princípios declarados na Carta del Paisaje de las Américas poderão optar pela ideia de bem patrimonial coletivo mais conveniente aos objetivos da intervenção que, toca alertar, nem sempre serão objetivos realmente coletivos e responsáveis com a alteridade. Assim, julga-se urgente a elaboração de uma conceituação para tal noção, mesmo que uma definição breve em seu glossário, já que é o espaço que o gênero Carta da Paisagem possibilita.

Reflitamos mais um pouco acerca de tal noção e logo chegaremos aos aspectos metodológicos enumerados nessa introdução. A palavra "patrimônio" remonta, em primeiro momento, a bens materiais repassados a herdeiros. Porém, toca aclarar, que tal conceituação foi ampliada, passando a fazer parte do interesse público; um "conceito nômade" que acompanha as constantes mudanças na sociedade, agregando em sua definição diversos adjetivos ao decorrer da história (Choay, 2001). Por conseguinte, a compreensão de patrimônio é ampliada para o patrimônio cultural e passa a abarcar bens materiais e imateriais possuidores de variados valores e atributos (SILVA et al. 2007). A partir de tal ampliação, conferiu-se ao bem patrimonial a função de personificação da memória coletiva de uma determinada sociedade. Desse modo, responsável por afirmar sua identidade cultural e comunicar tais legados para gerações futuras. No entanto, ainda que carregando a congruência entre os diferentes sujeitos, simultaneamente são destacadas as diferenças culturais ao definir um bem patrimonial coletivo (Pelegrini, 2008). Isso, pois o que é considerado como bem patrimonial por um determinado grupo social pode ser totalmente refutado por outro. Vale salientar que se entende por "coletividade" um agrupamento de indivíduos com inclinações díspares, mas que estabeleçam algum elo entre si, considerando ainda seu caráter mutável derivado das constantes transformações suscetíveis aos atores (Funari e Peregrini, 2009). 
Desse modo, fica evidente quão grande é a complexidade para a definição de um bem patrimonial coletivo. Complexidade essa vinculada ao fato do bem patrimonial coletivo ser fruto da interação de sujeitos distintos, com diferenças sociais, econômicas e culturais ocasionando uma multiplicidade de interpretações e apropriações desses bens, ficando claro que demasiadas são as nuances presentes na concepção do bem patrimonial coletivo, indaga-se: as metodologias utilizadas na construção das Cartas consideram o caráter intersubjetivo, conflituoso e transitório dos bens patrimoniais coletivos? Consideram as singularidades e particularidades, as contradições e as identidades? Ao final deste tópico, pretende-se responder tais questões.

A Carta del Paisaje de las Américas, como já aclarado nesse artigo, define o direito à felicidade como sendo o "bem patrimonial coletivo" das Américas a ser resguardado por meio da paisagem e segundo a lógica manifestada nos princípios declarados. Porém, pensemos em que medida é legítima essa definição. Como se definiu? Quem definiu? Como já deve ter ficado claro para o leitor, o que se pode retirar da leitura dialética da Carta é que essa se constitui enquanto síntese das demais Cartas nacionais e regionais já produzidas nas Américas. A metodologia por meio da qual essa síntese foi realizada, porém, não se aclara em nenhum momento do documento. Não se aclara, pois, como elucidado no tópico anterior, o gênero discursivo utilizado não impõe tal descrição metodológica. Ou seja, nenhuma das Cartas, - com exceção da Carta Venezuelana da Paisagem - por imposição centrípeta do gênero discursivo, apresenta sua metodologia, fato esse que nos impediu de encontrar aspectos metodológicos na superfície do texto, mas não impediu de encontrar pistas dessas metodologias. Nesse sentido, vê-se como necessário outro rápido mergulho nas Cartas, dessa vez, porém, em busca de processos que afirmem ou neguem a felicidade como bem patrimonial coletivo; em busca de aspectos metodológicos que validem ou desvalidem tal princípio norteador.

O primeiro fato empírico que colide com a definição da felicidade como a vontade comum de bem patrimonial coletivo a ser garantido através da paisagem, é o de que apenas três das dezesseis Cartas já produzidas nas Américas citam diretamente a felicidade, são elas: Carta colombiana, chilena e costarriquense. Tal fato nos faz interrogar se a felicidade é uma solicitação realmente coletiva? É uma solicitação retirada da realidade concreta?

Na Carta Colombiana da Paisagem, a primeira a ser elaborada no contexto das Américas, um dos princípios considera que: "El paisaje es fundamental en la calidad de vida de la sociedad". Da mesma forma, o referido documento estabelece como objetivo:

[...] promover el reconocimiento, la valoración, la protección, el planeamiento y la gestión sostenible de los paisajes conducentes al reconocimiento de la diversidad y los valores de los paisajes [...] reconocer que el paisaje es un recurso de bienestar individual y colectivo que, además de valores estéticos y ambientales, tiene una dimensión económica, cultural, social, patrimonial y de identidad. (Carta Colombiana del Paisaje, 2010, p.7) 
Como se pode notar, em alguns trechos dessa Carta não se fala diretamente da felicidade, ainda que se faça referência a dois aspectos muito relacionados a tal concepção (pelo menos no contexto colombiano) a saber: qualidade de vida e bem-estar - conceitos que, desde a Convênio Europeu da Paisagem, foram citados como qualidades das paisagens (European Landscape Convencion, 2000, p.1). Porém, a Carta Colombiana da Paisagem propõe como parte de suas medidas "[...] la identificación, el análisis y la cualificación de los paisajes [...]" (Carta Colombiana del Paisaje, 2010, p. 9), com base numa abordagem que formula expressamente "[...] el derecho de los ciudadanos a gozar del paisaje como componente de su bienestar, espacio para la felicidad y de mejoramiento de su calidad de vida." (Carta Colombiana del Paisaje, 2010, p. 9). Assim, o bem-estar é reconhecido como um dos valores e qualidades da paisagem colombiana, considerada então como um "espacio propicio para la felicidad" (Carta Colombiana del Paisaje, 2010, p. 9).

Posteriormente, fazendo referência ao documento colombiano, também em 2010, na Carta Costarriquense da Paisagem encontra-se:

\begin{abstract}
Como lo sostiene la Carta Colombiana del Paisaje, consideramos que contribuir a la felicidad de los seres humanos, favorecer el bienestar social e individual y responder a la necesidad pública de poder disfrutar del paisaje como expresión de la calidad de vida, así como desempeñar un papel activo en su transformación, son los desafíos que presenta el futuro a la sociedad y a la Arquitectura de Paisaje. (Carta Costarricense del Paisaje, 2010, p. 2)
\end{abstract}

Assim, entre os princípios desse documento, apresenta-se a paisagem como:

[...] un hecho de interés general y carácter colectivo, que presenta destacados rasgos nacionales entre los que es fundamental el reconocimiento de los ecosistemas que lo sustentan y la felicidad de las poblaciones que los habitan. [...] El paisaje es fundamental en la calidad de vida de la sociedad y por esto lo son también el derecho a la calidad ambiental y paisajística en la que se desarrolla la vida de los pueblos. (Carta Costarricense del Paisaje, 2010, p. 2)

Alerta-se, porém, que a base para se definir a centralidade da felicidade não deveria ser a Carta Colombiana da Paisagem; não deveria ser um princípio que derivou do estudo de uma realidade alheia. Por outro lado, deveria surgir das próprias vontades e preocupações do recorte espacial o qual está encarregada de representar; surgir do estudo da concreticidade singular da Costa Rica. Transportar princípios que emanaram do estudo de realidades alijadas é sempre um movimento metodológico agressivo para com as alteridades; um movimento despreocupado com a representação dessas; e, por fim, um movimento que pode infirmar os princípios declarados em qualquer Carta que assim o faça. Infirmar, pois, nessa lógica metodológica, os princípios não estariam sendo construídos como expressão coletiva de um território, região ou nação, mas como expressão teórica, transcendental e descolada da realidade geográfica, histórica e biológica específicas.

A última Carta que faz referência direta ao termo felicidade é a Carta Chilena da Paisagem, que em 2011 define paisagem a partir de uma abordagem sociocultural, e, entre outros aspectos, aponta que: "Como 
vehículo de valores positivos y caracteres de identidad, el Paisaje es un elemento fundamental para la calidad de vida de la sociedad y finalmente la felicidad a la que anhelamos todos." (Carta Chilena del Paisaje, 2011, p. 4).

Nessas primeiras Cartas Nacionais da Paisagem, a felicidade é abordada explicitamente a partir de um estreito vínculo com a paisagem, considerando-a como um "espaço para a felicidade", definindo "a felicidade como uma característica dos sujeitos que habitam nele", ou como "um desafio" ou "um desejo". No entanto, as demais Cartas - posteriormente redigidas - já não citam diretamente a felicidade como um conceito ou qualidade ligada à paisagem ou aos sujeitos, e passam a associá-la expressamente a outros conceitos como qualidade de vida e bem-estar.

No entanto, surpreende que em nenhum desses documentos se defina abertamente qual conceito de bem-estar, qualidade de vida e felicidade - conceitos, cabe destacar, com forte carga ideológica e subjetiva, o que se caracteriza como uma fragilidade, pois, assim como ocorre com a ideia de "bem patrimonial coletivo" no caso da Carta del Paisaje de las Américas, trata-se de um aspecto-chave para qualquer documento que procure servir como instrumento na elaboração de políticas de intervenção e gestão, a definição objetiva de certos conceitos e ideias. Da mesma forma, não é exposta a razão, ou os procedimentos metodológicos que permitiram reconhecer que a paisagem pode ser considerada por todos um "espaço para a felicidade".

Vários estudos sobre a felicidade, a partir de distintas abordagens (filosóficas, socioculturais ou psicológicas), reconhecem que o termo variou ao longo da história, de modo que não é possível imaginar que definição ele terá em um futuro próximo (Camalionte e Baccalandro, 2017). Reconhecem também que a felicidade é um fenômeno predominantemente subjetivo, com sentimentos de bem-estar e prazer, associado a vários aspectos, como otimismo, resiliência, saúde mental e, fundamentalmente, subordinados a traços psicológicos e socioculturais. Deve-se notar, portanto, que as Cartas estão baseadas em diferentes métodos e têm como objeto de análise distintas realidades históricas, geográficas, sociológicas e biológicas. A elaboração e declaração de seus conjuntos de princípios, portanto, deveria se dar através de consultas e pesquisas dos diferentes grupos sociais que compõem a realidade das Cartas; através da participação, também, de pesquisadores de diferentes áreas e especialidades. Ou seja, seguir uma metodologia participativa, integrativa e transdisciplinar ao definir ou traçar princípios e objetivos que envolvem conceitos subjetivos como qualidade de vida, felicidade e bem-estar. Nesse sentido, abrem-se questões: no processo de produção das Cartas que embasam a Carta del Paisaje de las Américas, diferentes grupos sociais, culturais e étnicos foram consultados para considerar a paisagem como um espaço para a felicidade? Foram os diferentes sujeitos, agentes e atores concretos que explicitaram uma máxima aspiração pela felicidade diante da paisagem que habitam? Se não, poderíamos definir a felicidade como bem patrimonial e coletivo? Como a Carta del Paisaje de las Américas poderia garantir, como instrumento ou declaração de princípio, a conquista coletiva dessa felicidade? 
Essas questões se apresentam como lacunas nesta análise e, por sua vez, levam-nos a procurar a possível falta de uma metodologia participativa na elaboração das Cartas Regionais e Nacionais da Paisagem. Parece-nos, porém, que foi a partir da elaboração de um primeiro documento (a Carta Colombiana) que os princípios e conceitos, nele construídos, passaram a ser tomados como universais (totalizadores) e, em processo de transferência transcendental, a anular (ou desestimar) algumas das singularidades das nossas paisagens americanas.

Cabe destacar que nem em todas as Cartas nacionais e regionais analisadas percebe-se essa reutilização. Apenas para mencionar um dos exemplos que sai dessa lógica de forma particularmente especial, a Carta da Paisagem Boliviana mostra claramente características muito típicas e singulares de suas paisagens. Pensemos na valorização da relação com a "Mãe Terra" e o caráter coletivo. A Bolívia é um país plural e multicultural, onde a diversidade é um patrimônio intangível que contribui para a manutenção de suas paisagens. A partir disso, o conceito de paisagem desenvolvido pelo grupo boliviano na Carta Boliviana da Paisagem inclui os sujeitos como parte da paisagem: "[...] el Paisaje es un bien que nos contiene... el paisaje es recíproco, porque es vivenciado a través de la sensibilidad de su gente." (Carta Boliviana del Paisaje, 2013, p.3). Neste sentido, entre seus valores, reconhece que: "Las intuiciones, los imaginarios, los mitos locales, generan el paisaje en sus diferentes dimensiones, el imaginario de la colectividad da una valoración especial única al paisaje." (Carta Boliviana del Paisaje, 2013, p.3). A partir deste e de outros valores é possível reconhecer como um de seus princípios que: "El paisaje natural y cultural es un bien común que debe ser preservado." (Carta Boliviana del Paisaje, 2013, p.3).

Sem dúvida, a coerência e originalidade desse documento é destacável, ao contrário do caso da Carta da Paisagem da América Central e do Caribe (2016), que, mesmo sendo uma Carta que "representa" toda uma região ontologicamente diversa, constituiu seus princípios através da cópia ipsis litteris dos princípios da Carta Costarriquense da Paisagem (2010) - aqui reside o segundo fato que põe em questão a definição da felicidade como bem patrimonial coletivo. Entretanto, deve-se aclarar que todo enunciado faz parte de um processo de comunicação dialógica ininterrupto. Não há enunciado isolado e, logo, não há Carta da Paisagem isolada. Toda Carta da Paisagem pressupõe aquelas que a antecederam e todas as que sucederão. Como a própria linguagem também é constituída nessa corrente dialógica, a produção textual-discursiva de cada sujeito não se forma somente a partir de uma voz, mas sempre a partir de muitas vozes, muitos dizeres. Não é a condição dialógica da linguagem que estamos indagando, mas os usos descuidados das vozes e dizeres alheios.

Essa Carta, com o intuito, talvez, de justificar a cópia dos princípios, junta de maneira reducionista e homogeneizadora o Caribe como parte da Mesoamérica1, declarando que: "constituyen una unidad

\footnotetext{
${ }^{1} \mathrm{O}$ que na atualidade entendemos por Mesoamérica é uma imensa área cultural pré-hispânica que discorre entre a zona nortecentro do México até a costa do Oceano Pacífico na Costa Rica (ROVIRA, 2007).
} 
geomorfológica y cultural a partir de un pasado histórico común y claras constantes en su paisaje natural y cultural" (Carta del Paisaje de Centroamérica y el Caribe, 2016, p.1). Portanto, essa Carta que, cabe destacar, foi escrita seis anos após a Carta Costarriquense da Paisagem, mas que reproduziu os mesmos princípios, não só desconsidera totalmente o Caribe insular com suas especificidades geográficas, culturais e históricas, como também o submete a declarações e acordos elaborados fora de sua realidade - um exemplo de uso descuidado das vozes e dos dizeres alheios na elaboração de um documento que procura ser reconhecido como aparelho consultivo a ser utilizado nas intervenções e gestão das paisagens dessa região.

No início desse tópico, indagávamos se as Cartas, que serviram de base para a construção da Carta del Paisaje de las Américas, utilizam métodos participativos e que garantem a representação das singularidades e particularidades. Como se declara apenas em uma das Cartas aspectos metodológicos, não se pode fechar tão facilmente essa questão. Porém, cabe destacar que o exercício de leitura dialética de todas as Cartas da Paisagem já produzidas na América nos possibilitou um dado que nos auxilia na resposta, a saber: a constatação de que existem usos descuidados do discurso de outrem nas cartas; a palavra alheia é, por vezes, tomada na forma de cópia ipsis litteris de princípios declarados entre as Cartas. Referimo-nos aqui ao mais emblemático dos casos, a saber: o da Carta da Paisagem da América Central e Caribe que copiou os princípios da Carta Costarriquense da Paisagem, como pode ser observado abaixo:

\footnotetext{
- El disfrute del paisaje es un derecho de todos los seres humanos

- El paisaje es un hecho de interés general y carácter colectivo, que presenta destacados rasgos nacionales entre los que es fundamental el reconocimiento de los ecosistemas que lo sustentan y la felicidad de las poblaciones que los habitan

- El paisaje es fundamental en la calidad de vida de la sociedad y por esto lo son también el derecho a la calidad ambiental y paisajística en la que se desarrolla la vida de los pueblos.

- El paisaje participa en el objetivo general de la sostenibilidad y de allí su importancia como instrumento de planificación del desarrollo sostenible portador de una visión integrada para los proyectos y políticas gubernamentales y la acción privada

- El paisaje está íntimamente ligado a la mitigación de los efectos del cambio climático entre ellos el calentamiento global y la urgente necesidad de reducirlo.

- El paisaje constituye parte fundamental del patrimonio natural y cultural y por lo tanto de las identidades regionales y nacionales por las que se debe velar para que sea respetado y preservado.

- El paisaje es un bien económico para la sociedad y un recurso favorable a la actividad económica que produce valor agregado, incrementa la producción y contribuye a la creación de empleo y nuevas tecnologías. (Carta Costarricense del Paisaje, 2010, p.3)
}

- El disfrute del paisaje es un derecho de todos los seres humanos.

- El paisaje es un hecho de interés general y carácter colectivo, que presenta destacados rasgos nacionales entre los que es fundamental el reconocimiento de los ecosistemas que lo sustentan y la felicidad de las poblaciones que los habitan.

- El paisaje es fundamental en la calidad de vida de la sociedad y por esto lo son también el derecho a la calidad ambiental y paisajística en la que se desarrolla la vida de los pueblos.

- El paisaje participa en el objetivo general de la sostenibilidad y de allí su importancia como instrumento de planificación del desarrollo sostenible portador de una visión integrada para los proyectos y políticas gubernamentales y la acción privada.

- El paisaje está íntimamente ligado a la mitigación de los efectos del cambio climático entre ellos el calentamiento global, la urgente necesidad de reducirlo y el manejo del riesgo sobre paisajes culturales en peligro de extinción y espacios públicos de gran uso y significación.

- El paisaje constituye parte fundamental del patrimonio natural, cultural y los paisajes rurales. Por lo tanto también lo es su valor en cuanto a las identidades regionales y nacionales, razón por la cual se debe velar para que sea respetado y preservado. 
- El paisaje es un indicador de la calidad de vida de la población y su bienestar colectivo. Es a la vez un bien económico para la sociedad y un recurso favorable a la actividad económica que produce valor agregado, incrementa la producción y contribuye a la creación de empleos, la innovación y el desarrollo de nuevas tecnologías. (Carta del Paisaje de Centroamérica y el Caribe, 2016, p.4)

No tópico anterior, quando refletindo sobre a noção bakhtiniana de tema, inferimos que as cartas são documentos únicos, pois têm funções únicas, sentidos únicos e, logo, temas também únicos e não reiteráveis. Uma vez que cada Carta se propõe a representar um recorte espacial específico e único, num dado tempo histórico não repetível, deve-se entender que a transposição de princípios de uma carta para outra será sempre um ato de violência para com o recorte espacial ao qual a Carta deveria representar. Não se trata de pensar o texto como algo puramente original e de negar a condição dialógica do enunciado. Pelo contrário. Assumimos que há uma heterogeneidade constitutiva nas Cartas e que essas, por sua vez, são resultado do encontro dialógico organizado por um sujeito (individual ou coletivo) que também se constitui por meio de uma relação dialógica com o outro. Porém, deve-se concordar que, nesse caso, a utilização do discurso de outrem para ditar os princípios pode significar o não compromisso com a representação das particularidades e singularidades da região em questão. É se utilizar de uma voz alheia e transcendental à região e, num mesmo movimento, ocultar e suprimir as vozes autóctones.

Portanto, pode se inferir de um movimento de cópia, que a metodologia utilizada não garante a representação das singularidades e particularidades do recorte espacial ao qual "representa" a Carta. Não garante, pois ao transportar princípios que foram construídos em um contexto geográfico particular distinto e ao tomar tais princípios como universais para toda uma região (diversa), estão se criando ideias fora do lugar; estão se impondo lógicas e intenções alijadas da realidade vivida, alijadas das regiões e paisagens reais. Indagamos: como a Carta del Paisaje de las Américas pode propor participação enquanto um de seus objetivos declarados, se no processo de construção dos princípios dos documentos que a embasam nem sempre se realizou a participação solicitada? Uma contradição que pode infirmar o dito documento como instrumento e enquanto declaração de princípios. Mesmo com todo esforço dos autores da Carta, o documento pode perder o sentido. Como construir princípios éticos fundamentais para intervir na paisagem através de uma "ética" despreocupada com a alteridade? Tal constatação fortalece nossa hipótese de que a Carta é uma declaração de princípios descolada das particularidades e singularidades inerentes ao continente americano; descolada não necessariamente por sua responsabilidade, mas pelo descompromisso metodológico de algumas das Cartas da Paisagem que serviram de base para sua construção.

\footnotetext{
2 O décimo segundo objetivo declarado na Carta roga: "Promover e incorporar la participación social como condición necesaria para las decisiones públicas de planificación, conservación, gestión y diseño de los paisajes americanos, además de promover la participación de la población en los proyectos y actividades de los planes de manejo del paisaje." (CARTA DEL PAISAJE DE LAS AMÉRICAS, 2018, p.9).
} 
Nesse sentido, defendemos que não se pode garantir o direito à felicidade como um bem patrimonial coletivo das Américas através de uma declaração constituída por princípios transcendentais - ainda que bem redigidos e assinados por acadêmicos carregadores do prestígio de autoridade da ciência - e que seguem uma lógica já tão criticada através, inclusive, de várias das categorias utilizadas no corpo da Carta; que seguem uma lógica homogeneizadora e reducionista - ainda que utilizando de argumentação persuasiva e aparentemente preocupada com a alteridade - e descolada da realidade concreta.

Um transcendentalismo metodológico que fica ainda mais evidente ao tomar, como objeto de reflexão, a única Carta que, desviando da imposição do gênero, nos oferece seus aspectos metodológicos de maneira explícita, a saber: a Carta Venezuelana da Paisagem. Essa declara que:

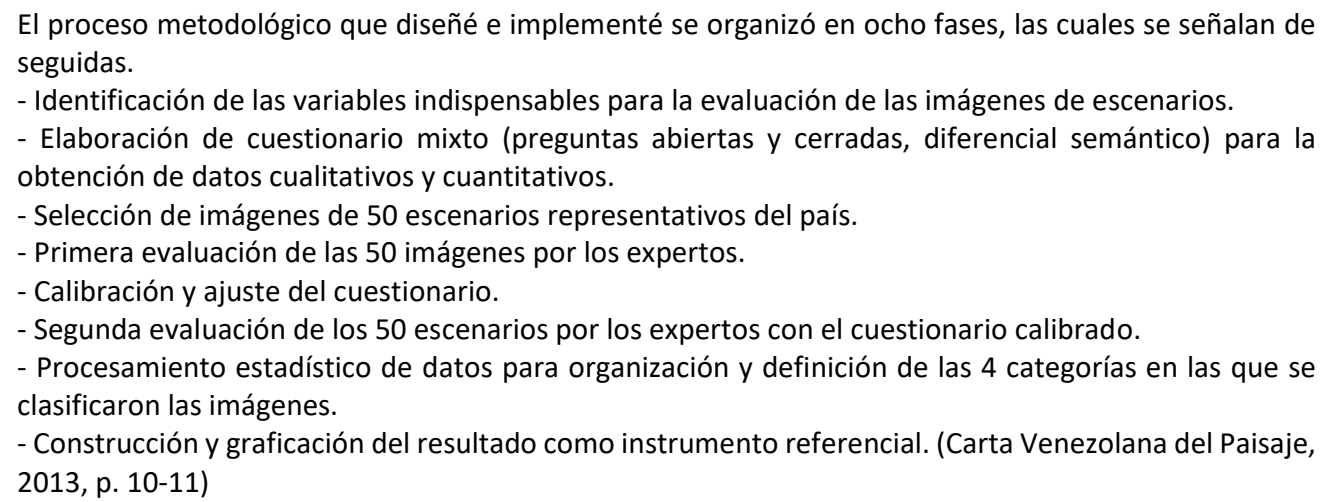

Quem selecionou os recortes de paisagens representativos do país? Seguiu-se uma lógica imanente ou transcendental no processo de seleção desses "escenarios"? Ouviram-se os diferentes sujeitos, agentes e atores concretos? Da maneira como está exposto na dita Carta, as respostas para nossas indagações ficam evidentes: quem selecionou foram os intelectuais, apenas. Tal fato configura uma lógica transcendental no processo de seleção dos "escenarios". Transcendental, pois quando não se consulta e, consequentemente, não se representa a alteridade, quando se vira ao rosto dos demais sujeitos, agentes e atores que compõem a realidade a qual a Carta está encarregada de representar, comete-se um ato de violência. Não se comprometer com a representação dessa alteridade, mas saber que a construção de seu documento pode ter consequências diretas nestes grupos humanos e em suas paisagens, representa algo que poderíamos chamar de desvio de olhar (virar ao rosto). Deixar de reagir ao Outro, recusar compreendê-lo e evitar o reconhecimento da alteridade é o que nomeamos aqui de cegueira (Baumam, 2014).

Cegueira, pois os riscos do não comprometimento com a representação da alteridade parecem cair na zona da retina de onde sai o nervo óptico da autora da Carta Venezuelana da Paisagem, que, portanto, não tem sensibilidade à luz - o chamado ponto cego. Deste modo, parece não perceber que de fato há uma descontinuidade que deveria aparecer; uma alteridade tornada invisível e que deveria ser considerada no ato de selecionar os escenarios e princípios representativos da Venezuela. Lembro-lhes que as Cartas da Paisagem, 
além de uma forma estrutural composta por elementos linguísticos específicos, são uma maneira particular de visualizar e representar uma dada realidade, cabe destacar, com uma dada intenção discursiva. Da forma com aqui está posto, a representação da realidade não tem sido comprometida com a alteridade.

O que deveria representar uma Carta da Paisagem? Seguimos defendendo que deveriam representar as paisagens vividas e reais e evitar a busca, sem sentido, por paisagens universalizantes. Nesse sentido, para se representar a "paisagem habitada", a "paisagem vivida", a "paisagem vernacular", ou seja, para representar paisagens Outras, é preciso um esforço metodológico muito maior (Jackson, 2003) do que o apresentado na Carta Venezuelana da Paisagem, por exemplo. Um esforço muito maior, pois o que caracteriza as paisagens vernaculares e, consequentemente, o que as torna difícil de perceber e de representar, é que elas, na maioria dos casos, não apresentam marcações políticas fortes. As paisagens vernaculares são muito mais flutuantes que as paisagens hegemônicas. Isso, pois enquanto as paisagens hegemônicas, conforme comenta Besse (2014a), caracterizam-se pelas noções de ruptura e de fundação (a marcação de território), as paisagens vernaculares são mais caracterizadas pela noção de adaptação às circunstâncias. São paisagens de continuidade temporal e fruto do cotidiano. São a personificação do nosso estar no mundo. Ao contrário das paisagens hegemônicas que são a tentativa de concretização de uma ideia ou de um arquétipo de identidade, as paisagens vernaculares não têm sua identidade determinada no princípio.

\footnotetext{
A elaboração vernacular da paisagem repousa, com efeito, sobre o costume, ou seja, não sobre um conjunto de princípios absolutos que viriam aplicar do exterior sobre o lugar, mas sobre um conjunto de hábitos, de práticas, de usos continuamente elaborados e ajustados ao contato com o lugar, numa relação de parceria, no curso do que poderíamos chamar uma conversação com o lugar. "Costumes", "práticas", "conversação": estamos aqui no universo de uma racionalidade contextual, em permanente evolução, sem identidade definida a priori [...] (Besse, 2014, p.251).
}

Fica evidente, portanto, que a maioria das Cartas da Paisagem, da forma como aí estão postas, não conseguem representar as paisagens vernaculares, as paisagens Outras. Não conseguem, sobretudo, por partirem de princípios metodológicos que desconsideram o costume e o conjunto de hábitos e práticas que derivam da relação de "conversação" que nos cita Besse. Percebido isso e diante da análise acima desenvolvida, voltemos a nossa questão fundamental: o direito à felicidade como bem patrimonial coletivo das Américas é uma vontade transcendental ou uma vontade concreta? Agora, sem dúvidas, respondemos que se trata de uma vontade transcendental e despreocupada com a realidade concreta.

\section{CONSIDERAÇÕES FINAIS}

Apesar do conjunto de críticas aqui elaborado, deve-se destacar que tal documento representa um avanço; representa um movimento de pensar nossas paisagens de maneira coletiva. Mas no mesmo movimento, mostra-nos também a dificuldade de operacionalizar um projeto coletivo; a dificuldade de 
construir coletivamente metodologias que possibilitem representar a alteridade das paisagens nos países e regiões que compõem as Américas.

Nesse sentido, ainda que a intenção desse projeto coletivo seja das melhores, a frágil base na qual se assenta a Carta del Paisaje de las Américas acabou por colocar em questão o documento. Um documento sem arrimo suficiente para garantir suas intenções iniciais. A Carta, como vimos, foi construída sob um solo movediço entregue por parte de algumas das Cartas Nacionais e Regionais da Paisagem já desenvolvidas nas Américas. O caráter movediço do solo deve-se, sobretudo, ao descompromisso com a alteridade e ao desejo, inconsistente, de universalizar e sintetizar um continente diverso e contraditório sem o devido compromisso metodológico coletivo. É por esse motivo que julgamos que os princípios nela declarados não são pensados e nem construídos de maneira a garantir a representação das singularidades e particularidades sociais, culturais, biológicas etc. Fato que nos faz inferir que os princípios são muito mais expressão transcendental da vontade de alguns intelectuais que uma expressão imanente e realmente concreta.

Devido à transcendentalidade dos princípios declarados na Carta, abre-se um risco, a saber: as realidades das Américas que são diversas, plurais, singulares, contraditórias e, cabe destacar, com formas de conceber, sentir e relacionar com a paisagem igualmente diversas, plurais, singulares e contraditórias, ao serem futuramente tocadas pelos instrumentos desenvolvidos a partir dos princípios universalistas declarados na Carta, certamente serão descaracterizadas por princípios descolados de sua realidade.

Devido à falta de precisão conceitual presente no documento, outro risco se abre, a saber: deixa-se aberta a possibilidade de manipulação subjetiva e ideológica dos princípios declarados. Fato esse que acaba por não assegurar que a utilização dos princípios declarados na Carta guiará sempre para a garantia coletiva do direito à felicidade.

Pôde-se inferir, também, que a escolha do gênero discursivo não garantiu a vontade de servir como o instrumento que viabilizará a conquista do direito à felicidade como bem patrimonial coletivo das Américas. Nesse sentido, a Carta deve se assumir enquanto declaração de princípios éticos fundamentais que servirá para embasar a construção dos "verdadeiros" instrumentos que, por sua vez, deveriam permitir objetivar a já citada vontade ilegítima e transcendental da felicidade. Cabe destacar que a ilegitimidade da vontade de garantia do direito à felicidade enquanto bem patrimonial coletivo se deve, sobretudo, ao transcendentalismo metodológico que marcou a construção de parte das Cartas Nacionais e Regionais. Por ter sido construída enquanto síntese das Cartas Nacionais e Regionais, qualquer princípio que viesse a ser elencado na Carta como objetivo maior seria igualmente infirmado e ilegítimo, pois não seriam concretos, mas transcendentais da mesma forma. 
Fica evidente, portanto, que da forma como aí está posta, trata-se de uma Carta que não se sustenta e que não deveria sustentar intervenções nas paisagens. Uma Carta que não servirá como instrumento e para que possa servir efetivamente como declaração de princípios, deve-se propor a realização de uma revisão metodológica em diversas Cartas Nacionais e Regionais da Paisagem; realizar uma sensibilização metodológica coletiva em direção da representação de paisagens Outras.

Chegando nas últimas linhas dessa recepção crítica, chamamos atenção, especialmente, para a necessidade de superação desse transcendentalismo que marcou a construção de nossas Cartas Nacionais, Regionais e, consequentemente, de nossa Carta Continental da Paisagem; para a necessidade de abrir-nos em direção ao Outro. O que só se alcançará na medida em que os autores das Cartas Regionais, Nacionais e Continental forem, efetivamente, reeducados no sentido de comover-se com e pelo Outro; na medida em que façam uso de metodologias que estejam comprometidas com a representação da alteridade existente nos recortes espaciais aos quais estão encarregados de representar. Só assim será possível construir Cartas que possibilitem a representação de paisagens Outras; que possibilitem a representação de paisagem vernaculares e de formas Outras de sentir, significar e relacionar com o mundo.

Mesmo diante de tais possibilidades de correção, cabe destacar, porém, que efetivamente não temos certeza de que seja possível fazer a síntese proposta pela Carta; a síntese dessas diferentes problemáticas paisagísticas num pensamento global da paisagem. Mas também não temos certeza de que seja necessário. Tentemos, então, propor outra coisa, isto é, uma unidade sem síntese ou, mais precisamente, sem totalização. Em outros termos, vamos aceitar o deslocamento, a passagem de um discurso a outro discurso, de um ponto de vista a outro ponto de vista, de uma paisagem a outra paisagem. Afinal, "não seria a experiência paisagística por excelência a do pensamento aberto?" (Besse, 2014, p.65).

\section{AGRADECIMENTOS}

Agradece-se à Coordenação de Aperfeiçoamento de Pessoal de Nível Superior (CAPES) e ao Conselho Nacional de Desenvolvimento Científico e Tecnológico (CNPq), pelo apoio financeiro concedido para a realização das pesquisas, ora em andamento, dos autores deste artigo cujos resultados foram utilizados na presente abordagem.

\section{REFERÊNCIAS}

ABBAGNANO, Nicola. Dicionário de Filosofia. São Paulo: Matins Fontes, 2007, 696p.

BAKHTIN, Mikhail. Estética da Criação Verbal. 3a edição, São Paulo: Martins Fontes, 2000, 421p.

BAKHTIN, Mikhail. Estética da criação verbal. 2ª edição, São Paulo: Martins Fontes, 1997, 421p. 
BAKTHIN, Mikhail. Problemas da poética de Dostoiévski. São Paulo: Forense-Universitária, 2008, 340p.

BAUMAN, Zygmunt. Cegueira moral. Rio de Janeiro: Zahar, 2014, 263p.

BESSE, Jean-Marc. Entre a geografia e a ética: a paisagem e a questão do bem-estar. GEOUSP: Espaço e Tempo, São Paulo, v.18, n.2, p. 241-252. 2014.

BESSE, Jean-Marc. O gosto do mundo: exercícios de paisagem. Rio de Janeiro: EdUERJ, 2014a, 234p.

BRAIT, Beth; PISTORI, Maria Helena Cruz. A produtividade do conceito de gênero em Bakhtin e o Círculo. ALFA: Revista de Linguística, São José do Rio Preto, v.56, n.2, p. 371-401. 2012.

CAMALIONTE, Letícia George e BOCCALANDRO, Marina Pereira Rojas. Felicidade e bem-estar na visão da psicologia positiva. Bol. Acad. Paul. Psicol. São Paulo, v.37, n.93, p. 206-227. 2017.

CARTA BOLIVIANA DEL PAISAJE. 2013, p.15. Disponível em: http://www.lali-iniciativa.com/wp-content/uploads/2019/03/CARTABOLIVIANA-DELPAISAJE.pdf. Acesso em: 23 de setembro de 2019.

CARTA BRASILEIRA DA PAISAGEM. 2012, p.28. Disponível em: http://www.lali-iniciativa.com/wpcontent/uploads/2019/03/BRASIL Carta-da-Paisagem-.pdf. Acesso em:23 de setembro de 2019

CARTA CHILENA DEL PAISAJE. 2011, p.7. Disponível em: http://www.lali-iniciativa.com/wp-content/uploads/2019/03/CHILE-cartadel-paisaje-2011.pdf. Acesso em: 23 de setembro de 2019.

CARTA COLOMBIANA DEL PAISAJE. 2010, p. 16. Disponível em: http://www.lali-iniciativa.com/wpcontent/uploads/2019/03/COLOMBIA-Carta-del-Paisaje 2010.pdf. Acesso em: 23 de setembro de 2019.

CARTA COSTARRICENSE DEL PAISAJE. 2010, p.6. Disponível em: http://www.lali-iniciativa.com/wp-content/uploads/2019/03/COSTARICA-Carta-del-paisaje-octubre 10.pdf. Acesso em: 23 de setembro de 2019.

CARTA DEL PAISAJE DE CENTROAMÉRICA Y EL CARIBE. 2016, p.9. Disponível em:http://www.revistas.unam.mx/index.php/mecedupaz/article/view/68915. Acesso em: 23 de setembro de 2019.

CARTA DEL PAISAJE DE LAS AMÉRICAS, 2018, p.12. Disponível em: https://www.ufpe.br/documents/39726/0/08.Carta+de+las+Americas final 12.pdf/1c7926b7-4667-4bee-ae7b-fce008af9f9b. Acesso em: 23 de setembro de 2019.

CARTA MEXICANA DEL PAISAJE. 2011, p. 11. Disponível em: http://www.lali-iniciativa.com/wpcontent/uploads/2019/03/MexicoC. PAISAJE 2.pdf. Acesso em: 23 de setembro de 2019.

CARTA VENOZOLANA DEL PAISAJE. 2013, p.14. Disponível em: http://www.lali-iniciativa.com/wp-content/uploads/2019/03/CartaVENEZOLANA-del-Paisaje.pdf > [Consulta: 23 de setembro de 2019]

CARTA DEL PAISAJE DEL URUGUAY, 2012, p.7. Disponível em: http://www.lali-iniciativa.com/wpcontent/uploads/2019/03/URUGUAY-CARTA-DEL-PAISAJE-2012.pdf> [Consulta: 23 de setembro de 2019]

CHOAY, Françoise. A alegoria do patrimônio. São Paulo: Estação de Liberdade: UNESP, 2001, 281p.

DISCINI, Norma. Para o estilo de um gênero. Bakhtiniana, Rev. Estud. Discurso. São Paulo, v.7, n.2, p.75-94. 2012

European Landscape Convencion, p. 1-8, 2000. Disponível em: https://rm.coe.int/1680080621. Acesso em: 23 de setembro de 2019.

FUNARI, Pedro Paulo; PELEGRINI, Sandra de Cássia Araújo. Patrimônio histórico e cultural. Rio de Janeiro: Zahar, 2006, 72p.

JACKSON, John Brinckerhoff. La découverte du paysage vernaculaire. Arles: Actes Sud/École nationale supérieure du paysage, 2003, $277 \mathrm{p}$.

PELEGRINI, Sandra C. A. O Patrimônio Cultural e a materialização das memórias individuais e coletivas. Patrimônio e memória, São Paulo, v. 3, n. 1, p. 87-100. 2007

POSSENTI, Sírio. Enunciação, autoria e estilo. Revista da FAEEBA, Salvador, 2001 v.15, n.1, p. 15-21. 2001.

ROVIRA, Rossend Morgado. Mesoamérica: concepto y realidad de un espacio cultural. Revista sobre Arqueología en Internet, v.8, n.2, p. 1-11. 2007.

SILVA, Aline de Figueirôa; BRAGA, Anna Caroline; GAMEIRO, Fabiana Gonçalves; LIRA, Flaviana Barreto; SÁ CARNEIRO, Ana Rita; MELO, Vera Mayrinck. Os valores patrimoniais da paisagem cultural: uma abordagem para processos de intervenção. Paisagem Ambiente: ensaios, São Paulo, v. 10, n. 24, p. 297-308. 2007 